\title{
Policy Framework for Education Development in Nepal
}

\author{
Pramila Neupane ${ }^{1}$ \\ ${ }^{1}$ University Education Center, Gunma University, Japan \\ Correspondence: Pramila Neupane, University Education Center, Gunma University, 4-2 Aramaki, Maebashi, \\ Gunma, Japan. E-mail: p.neupane@gunma-u.ac.jp
}

Received: September 19, 2019

Accepted: October 28, 2019 Online Published: December 30, 2019

doi:10.5539/ies.v13n1p89

URL: https://doi.org/10.5539/ies.v13n1p89

\begin{abstract}
This exploration of challenges and barriers to inclusion in Nepal elaborates a conceptual framework for education development in a diverse society. As Nepal is a highly diverse, caste-based, multi-ethnic, and multi-linguistic society with very low development indicators, the article focuses on barriers to education and related issues across different socioeconomic groups. A systematic review of the relevant literature forms the basis for the design of a practical approach to education development for this diverse society in light of education policy trends in Nepal since 1950. The five proposed steps for education policy formulation and implementation include an in-depth analysis of the existing situation and outcome assessments. The proposed approach will enable local governance institutions to design and implement pragmatic provisions for education development at local level in the context of a new constitution that mandates local government management of school education.
\end{abstract}

Keywords: barriers to education, diverse society, education policy, educational development framework, Nepal

\section{Introduction}

Nepal's new constitution created a significant opportunity for education development. School-level education now falls under the jurisdiction of municipal government, and the involvement of local government and local communities can be expected to deliver better results, as the beneficiaries of education play a central role in school management. In a diverse society like Nepal, local government autonomy in managing local activities such as school education can promote more effective governance according to local needs and preferences (Faguet, 2013). Equally, however, this new responsibility poses challenges for local government, which lacks basic knowhow, expertise, and resources. According to Daly (2019), although the government is authorized to formulate necessary legislation according to need, the new legislative and regulatory frameworks are inadequate. The new highly decentralized state model represents a revolutionary process of transformation, and local and central government institutions must simultaneously resolve multiple existing problems. In that context, the present paper seeks to develop a conceptual framework that can be of practical use to policymakers and education practitioners at local level.

The conceptual framework elaborated here informs the design of a practical approach to education development in a diverse society. Based on a comprehensive review of the related literature and an assessment of education policy trends in Nepal, the proposed framework encompasses three domains: (1) socio-cultural and developmental diversity; (2) policy formulation and implementation and monitoring of results; and (3) education outcomes and socioeconomic development. In the first domain, the framework proposes two steps: understanding local socioeconomic conditions and identifying education barriers and prospects. The second domain also entails two steps: analyzing education inputs and outputs and aligning these with the Education Production Function (Britton \& Vignoles, 2017). Finally, in the third domain, analysis of the socioeconomic impacts of education clarifies the relationship between education and other development outcomes at local level.

\section{Literature Review}

\subsection{Barriers to Education: Global Context}

Barriers to education are multidimensional. The most critical of these dimensions is gender, as significant levels of inequality of access and outcome persist between women and men at all levels of education and in every country and community (Hyde, 1993; Smock, 1981; Unterhalter, 2008). Of more immediate interest here is that this inequality is more pronounced in less developed countries and in less developed communities within those 
countries. Despite the continuous advance of human civilization, women continue to encounter multiple barriers to educational attainment (Neupane, 2017), which also include caste/ethnicity, race, religion, disability, income, and location (Glewwe \& Muralidharan, 2016).

The numerous benefits of educating girls are widely documented (e.g., Slaughter-Defoe, Addae, \& Bell, 2002), and there is strong evidence that the most effective pathway for human improvement in underdeveloped areas is the schooling of girls and women (R. LeVine, S. LeVine, \& Schnell, 2001). Conversely, the failure to educate girls is clearly detrimental to the girls themselves, as well as to families, societies, and states. Uneducated girls are more likely to be marginalized — less healthy and less skilled, with fewer choices, and ill-prepared to participate in the political, social, and economic development of their communities. The children of uneducated, marginalized girls are also at higher risk of poverty, infectious disease (e.g., HIV/AIDS), sexual exploitation, and violence. Despite growing international awareness and campaigning, some governments appear apathetic (LeVine et al., 2001) about positive action to promote the education of girls.

This gender disparity is embedded in economic, social, and cultural factors that together make access to education more challenging for girls (Kays, 2003; Unterhalter, 2005). Even those who are in school also face many barriers to quality education, with significant attainment gaps across socioeconomic groups. According to UNESCO (2010), 72 countries have huge gender gaps in primary and secondary education; of these, 63 (including Nepal) have a significant gender gap in secondary education. These disparities are a consequence of multiple barriers and ultimately undermine socioeconomic development at national level, as well as individual health and prosperity.

In South Asia, gender discrimination is highly cited as a source of women's educational disadvantage (Bhagavatheeswaran et al., 2016). The region has the largest numbers of out-of-school children: 8.2 million at primary level and 23.6 million at secondary level (UNESCO, 2018), and the quality of education is very low, as millions of primary school graduates lack foundational literacy and numeracy. The numerous barriers include lack of suitable schools, unaffordable fees, unavailability of toilets, and sexual harassment. Along with widespread poverty and other economic barriers, early marriage and other deep-rooted sociocultural factors continue to undermine gender equality in South Asia, where ethnic fragmentation is more complex than in most other regions. For example, India is highly fragmented in terms of religion, culture, and languages (Okediji, 2005), and the caste system practiced by Hindus, the country's dominant religious denomination, exacerbates ethnic differentiation by creating a social hierarchy (Sengupta \& Sarker, 2011). The recent conflict in Indonesia, particularly during the post-Suharto regime, has an ethno-religious dimension, as in the conflict between Muslims and Christians in places such as Makasar and Ambon (Buttenheim \& Nobles, 2009). Similarly high levels of ethnic diversity have driven ongoing sociopolitical conflict in China, Vietnam, Thailand, Myanmar, and the Philippines (Ekeh \& Smith, 2007; Gobrin \& Andin, 2002).

In a review of the relevant literature, Haider (1996) categorized barriers to education into three groups; traditional and attitudinal, financial, and infrastructural. Although Haider's work dates back a couple of decades, it remains relevant in the current global context. Each of these barriers is discussed below.

\subsubsection{Traditional and Attitudinal Barriers}

In patriarchal societies, educating daughters is generally viewed as wasteful, as they will ultimately be married into another family (Raynor, 2005). This argument is often deployed to justify the exclusion of girls from school. Raynor (2005) and Shekh (2001) observed that parents are unwilling to invest in their daughters' education for several reasons. First, the benefits of investing in girls' education are often uncertain, as paid job opportunities for girls are limited. This discourages many parents from investing in their daughters' education, as they would be unable to recoup that investment. Secondly — and most crucially in patriarchal societies - any income earned by an educated married daughter would benefit her husband's family rather than her parents. Third, as sons typically take care of their aging parents in many societies like Nepal and India, educating sons is seen as an investment for old age. Finally, boys enjoy more job market opportunities than girls. In patriarchal societies, all of these factors present formidable obstacles to girls' education.

\subsubsection{Financial Barriers}

For many low-income families in the developing world, girls' schooling is considered a "luxury" (Haider 1996, p. 120). Economic hardship makes progress toward educational equity more difficult despite gender-specific and other targeted policy interventions and provisions. The evidence suggests that, in South Asian and North African countries, low levels of income in combination with low parental demand for education account for most of the barriers to female participation in education, especially in rural areas (Dundar \& Haworth, 1993). 


\subsubsection{Infrastructural Barriers}

The literature also highlights school location as a major barrier to girls' school enrollment and attendance, especially at secondary level (Dundar \& Haworth, 1993; Nussbaum, 2003; World Bank, 1994). In most developing countries, secondary schools are generally established in relatively developed centers, and most girls, especially those from far-flung villages, have limited access to such schools. For instance, the World Bank (1994) found that distance to school reduced girls' enrollment in Ghana as compared to boys, while paved roads helped to reduce girls' dropout rates by $5 \%$ in Morocco. The inverse relationship between distance and girls' school enrollment and attendance reflects culturally conservative parents' concerns about their daughters' safety when commuting to school on foot.

In some cultures, girl-only schools have boosted enrollment, attendance and participation in school activities (Dundar \& Haworth, 1993). According to Hamamsy (1994), conservative families favor single-sex schools that will maintain their daughters' "purity," and they may be concerned to protect their daughters from harassment or unwanted contact with male peers and male teachers (Haider, 1996). According to Daniel (2006) and Webster (1999), sexual exploitation by male peers and teachers and unexpected pregnancy have contributed significantly to female dropout from secondary and post-secondary education.

\subsection{Barriers to Education: Nepalese Context}

The academic literature on gender, caste, and ethnic barriers to education in Nepal is limited, and empirical studies are rare. However, donor-funded study projects occasionally produce reports. This section reviews these reports, along with relevant scholarly works.

\subsubsection{Sociocultural Barriers}

Sociocultural values and norms that discriminate against girls and women are deeply rooted in Nepali society. For instance, early marriage, son preference, and the traditional view of girls as someone else's property hinder both girls' education and national development (Sapkota et al., 2019). Another major obstacle is the caste system, which persists despite legislative countermeasures. This creates psychological and physical barriers to education and other services for Dalits, Nepal's lowest caste, which are considered untouchable in society (DFID, 2006). The caste system also discriminates against the Janajati or indigenous peoples, creating barriers to their children's education (CERID, 2005), and a majority of Janajati people are marginalized socially, economically, politically, and educationally (Bennett, 2008). Individual behavior, obligations, and expectations are caste- and ethnic group-specific, limiting access to basic social services, property, and political power (Lawoti, 2010). In summary, ethnicity, caste, and religious identity are major determinants of exclusion in Nepal (Manzoor \& Govinda, 2010).

Language represents another sociocultural barrier to education. Nepal's National Census of 2011 identified 123 languages spoken by various ethnic and minority groups while Nepali, the mother tongue and only official language, is spoken by just under half of the population (Central Bureau of Statistics, 2011). Janajati students whose mother tongue is not Nepali are disadvantaged, as most courses are offered in Nepali. According to recent data, textbooks for the basic education level are developed and published in only 24 languages (Ministry of Education, Science and Technology, 2017), and a lack of trained teachers means that teaching in the mother tongue has not proved effective (Phyak \& Ojha, 2019), impacting access to education as well as quality of learning.

\subsubsection{Financial Barriers}

Poverty is another common barrier to education in Nepal (Bista, 2004), and girls' education opportunities are further reduced when household resources are limited as a consequence of low household income, girls' domestic workload, the high opportunity cost of educating girls, and the indirect costs of education (Neupane, 2017).

\subsubsection{Infrastructural Barriers}

In Nepal, a number of minor rules and regulations, ranging from paperwork to other practical matters, undermine children's education (Mathema, 2007). For instance, although many poor families do not possess citizenship documents or children's birth certificates, parents may be asked to produce such documents at the time of enrollment (Neupane, 2017). School hours (10 am to $4 \mathrm{pm}$ ) do not suit most families whose main occupation is agriculture, as children are encouraged to engage in agricultural work rather than going to school.

Additionally, school facilities are not sufficiently girl-friendly to meet privacy and safety needs. In most schools, for instance, there are still no separate latrine arrangements for girls, which discourage many girls from attending 
school (Bista, 2004). Although the government has prioritized school water, sanitation, and health facilities, $99 \%$ of girls' toilets are not suitable for menstrual hygiene management. For that reason, many secondary-level girls do not attend school during their menstrual period (CERID, 2012).

In relation to school management, public schools whose pupils come from poorer households are not well managed (Thapa, 2013), and the lack of qualified teachers is reflected in a poor learning atmosphere and teaching practices that fail to engage. Public schools are seen to provide irrelevant, low-quality education, which has been identified as a key reason for parents' decision to withdraw their children from public schools and to enroll them in private schools. This is an increasing trend, as private schools are seen to provide a higher quality of education and other services (Neupane, 2017).

\subsubsection{Mental, Physical, and Other Health-Related Barriers}

In Nepal, disability is viewed as reparation for sins committed by the individual in previous lives, and people with disabilities are often marginalized by family and society. This is especially the case for women with disabilities, who face multiple barriers to education and other services. Sadly, the mothers of people with disabilities are blamed as alachhini (bringers of bad luck) (UNDP, 2004). According to Panthi (2004), more than $70 \%$ of people with disabilities in Nepal live with this stigma and find it extremely difficult to maintain their dignity. However, the data are not consistent and vary according to source (UNDP, 2004).

Limited access to modern healthcare facilities and lower utilization of health services contribute to high maternal and infant mortality rates in Nepal, again creating barriers to education. In a society dominated by males, women do not enjoy the freedom of marital or reproductive choice, and as a result, unwanted pregnancies are widespread in Nepal (Bastola, Neupane, Hadkhale, \& Kinnunen, 2016).

\section{Consequences and Policy Response}

As a result of the barriers to education described above, lower caste groups and the ethnic minority score poorly on indicators for education, as well as health and income. Lower secondary and secondary education statistics reveal that children from Dalits (the lowest caste) and Janajatis (an ethnic minority) are less likely to enroll than other castes and ethnic groups, and their dropout rate is very high (MOEST, 2017; Lohani et al., 2010). Although the caste issue has not received significant research attention, the few available studies suggest that caste has a strong effect on school participation (Stash \& Hannum, 2001; Jamison \& Lockheed, 1989).

There is a high level of educational deprivation among Dalits in Nepal, with literacy rates of only $52.4 \%$, well below the national average of $65.9 \%$. Among Dalit women, the literacy rate falls to $45.5 \%$ (Nepal National Dalit Social Welfare Organization, 2015). With an average 2.1 years of schooling, Dalit high school and university graduation rates are just $3.8 \%$, and $0.4 \%$, respectively, as compared to national averages of 3.62 years, $17.6 \%$, and 3.4\%, respectively (National Planning Commission, 2008). In total, $42 \%$ of Dalits fall below the poverty line, which is $17 \%$ higher than the national average for poor living conditions; for Dalit girls and women, the situation is even worse.

This low educational status has remained one of the major barriers to Dalits' human development, and as in many other countries, Nepal's government has declared its commitment to inclusive education. The concept of inclusive education first emerged during the 1960s in Europe, and most developed countries have long since addressed this issue. However, the issue was neglected for many years in Nepal's education policy. Khaniya (2007) defined inclusiveness in education as follows:

By inclusiveness in education, we usually understand the inclusion in student body of a full range of potential learners at school and college level including those with various barriers to learning like poverty, ethnicity, disability, gender, distance, language etc., and the provision of appropriate curriculum arrangements and support measures as required for effective learning resulting positive outcomes. (pp. 65-66)

To implement inclusive education, three main issues must be addressed: adequate school space, parental demand, and discriminatory treatment in schools (World Bank, 2006). Although Nepal's government has committed to inclusive education, effective implementation of such a program remains a distant prospect. The government's policies and priorities, especially for basic education, are set out in the EFA National Plan of Action 2001-2015. This rights-based approach aspires to an overall framework for school education from early childhood development to secondary level. However, the plans, programs, and goals identified in the EFA National plan have failed to address the barriers to education described above.

Table 1 shows the evolution of inclusive education policy in Nepal. While not all of the initiatives to achieve gender justice have been effective, there are signs of a real commitment to greater inclusion. 
Table 1. Education policies and programs for inclusion

\begin{tabular}{|c|c|c|}
\hline $\begin{array}{l}\text { Education } \\
\text { Plan/Commission Reports }\end{array}$ & Policy Intent & Proposed Programs \\
\hline NNEPC (1955) & $\begin{array}{l}\text { To improve women's skills and knowledge to enable } \\
\text { them to better perform their traditionally assigned roles }\end{array}$ & Adult literacy \\
\hline ARNEC (1960) & $\begin{array}{l}\text { - Continuation of NNEPC policy along with } \\
\text { community development and basic needs } \\
\text { components } \\
\text { - Ensure that neither girls nor boys are deprived } \\
\text { of primary education }\end{array}$ & $\begin{array}{ll}\text { - } & \text { Adult literacy } \\
\text { - } & \text { Expansion of primary schools. }\end{array}$ \\
\hline NESP (1970-1975) & No segregated schools & Co-education \\
\hline NHLEC (1992) & $\begin{array}{ll}\text { - } & \text { Increase women's literacy } \\
\text { - } & \text { Women and girls assigned priority at all levels } \\
\text { of education } \\
\text { - } & \text { Priority assigned to teacher training of women } \\
\text { - } & \text { Provision of scholarships for women and girls } \\
\end{array}$ & $\begin{array}{l}\text { - Literacy and/or education for women's } \\
\text { empowerment } \\
\text { - } 70 \% \text { of scholarships to be awarded to women }\end{array}$ \\
\hline $\begin{array}{l}\text { MoE Policy } \\
(2003 / 2004)\end{array}$ & Provision of at least two lady teachers per school & $\begin{array}{l}\text { Ten months of pre-service training with scholarship } \\
\text { for women with potential from ethnic groups and } \\
\text { Dalits }\end{array}$ \\
\hline $\begin{array}{l}\text { EFA Policy } \\
(2002-2015)\end{array}$ & $\begin{array}{l}\text { - Gender mainstreaming } \\
\text { Training teachers to be gender-sensitive and } \\
\text { socially inclusive }\end{array}$ & $\begin{array}{l}\text { Gender training for head-teachers, teachers, and } \\
\text { SMC members }\end{array}$ \\
\hline $\begin{array}{l}\text { SSD Program } \\
(2016-2022)\end{array}$ & $\begin{array}{l}\text { Quality education for SDGs } \\
\text { - } \quad \text { Education development as a key means of } \\
\text { achieving SDGs } \\
\text { Decentralize responsibility for school sector to } \\
\text { local government } \\
\text { Four objective pillars: equity, quality, } \\
\text { competence, and relevance } \\
\text { Focus on vocational education that is relevant to } \\
\text { local needs }\end{array}$ & $\begin{array}{l}\text { - Restructure school organizations based on } \\
\text { new rules and regulations } \\
\text { Enhance access to basic education, focusing } \\
\text { on remote areas, gender, and ethnic minorities } \\
\text { Develop model schools in all provinces and } \\
\text { districts }\end{array}$ \\
\hline
\end{tabular}

Note. NNEPC: Nepal National Education Planning Commission; ARNEC: All Round National Education Committee; NESP: National Education System Plan; NHLEC: National Higher Level Education Committee; MoE: Ministry of Education, EFA: Education for All, SMC: School Management Committee; SSD: School Sector Development, SDGs: Sustainable Development Goals. Source: Timsina (2004) in UNESCO (2005), MoE (2017).

Inclusiveness in all aspects of development, including education, has been a significant political issue since 1990, when Nepal became a multiparty democracy and many diverse groups began to express their opinions openly and to assert their identities and rights. Nevertheless, the established order remains dominated by male Brahmans, Chhetries (including Thakuris), and educated urban Newars. Women, Dalits and tribal indigenous groups like the Janajatis remain outside the mainstream political and development agenda (Bhattachan, 2003). Social inclusion has become a hot issue and was even included as one of the four pillars of the national development plan (2002-2007), widely known as the Tenth Plan. As a result, there is now a greater understanding that social exclusion is a structural problem that cannot be solved by welfare handouts.

\section{Framing the Education Development Model}

Based on a review of the relevant literature and policy, Figure 1 presents a framework for education development in Nepal. The five steps for formulating and implementing effective education policy are grouped into three categories. First, to formulate appropriate policy, it is essential to understand the current situation. For that reason, the first and second steps examine sociocultural and developmental diversity. The first step focuses on understanding the caste/ethnic composition of the local community, as most districts, villages, and even small communities within villages comprise different caste/ethnic groups. This composition contributes in turn to the extent of barriers to education (Neupane, 2017). For instance, in a village where they are in the majority, a Janajati group faces fewer barriers to education than if they were a minority. It follows that no single policy to 
support disadvantaged Janajati (or Dalits) can be equally effective in all situations. Brahman or Chhetri groups may also need support if they constitute a very small group within a given community. In general, educational and other developmental gaps among sociocultural groups must be understood in the local context.

In the second step exploring barriers to education, it is especially important to ask in detail about gender barriers, which are known to differ across caste/ethnicity and rural/urban context (Neupane, 2017). In particular, the literature highlights three major types of barrier, which although common to all developing countries, differ significantly across local contexts. It is equally important to explore the prospects for education development in the local area, in terms of how many prospective teachers are available, what kind of education is needed, and the current status of public and private schools in the area. Together, these first and second steps constitute a situational analysis.

The third and fourth steps relate to education policy formulation and implementation and monitoring of results. The third step focuses on the analysis of education inputs. While government budget provision is essential, it is even more important to understand education spending and available resources in order to identify both resource gaps and demand/supply gaps. This also helps to clarify the private and social costs of education at local level.

In the fourth step, education goals and targets should be clarified on a timeline. Based on knowledge of local conditions (from steps one and two) and resource constraints and availability (from step 3), a number of key questions must be addressed. What we want to achieve by when? What policies and programs are required to achieve these goals? What type of institutional framework is necessary? As the most important step, this demands significant resources and effort. Steps three and four are informed by the Education Production Function framework, which addresses the proper use of education inputs to achieve desired education outputs.

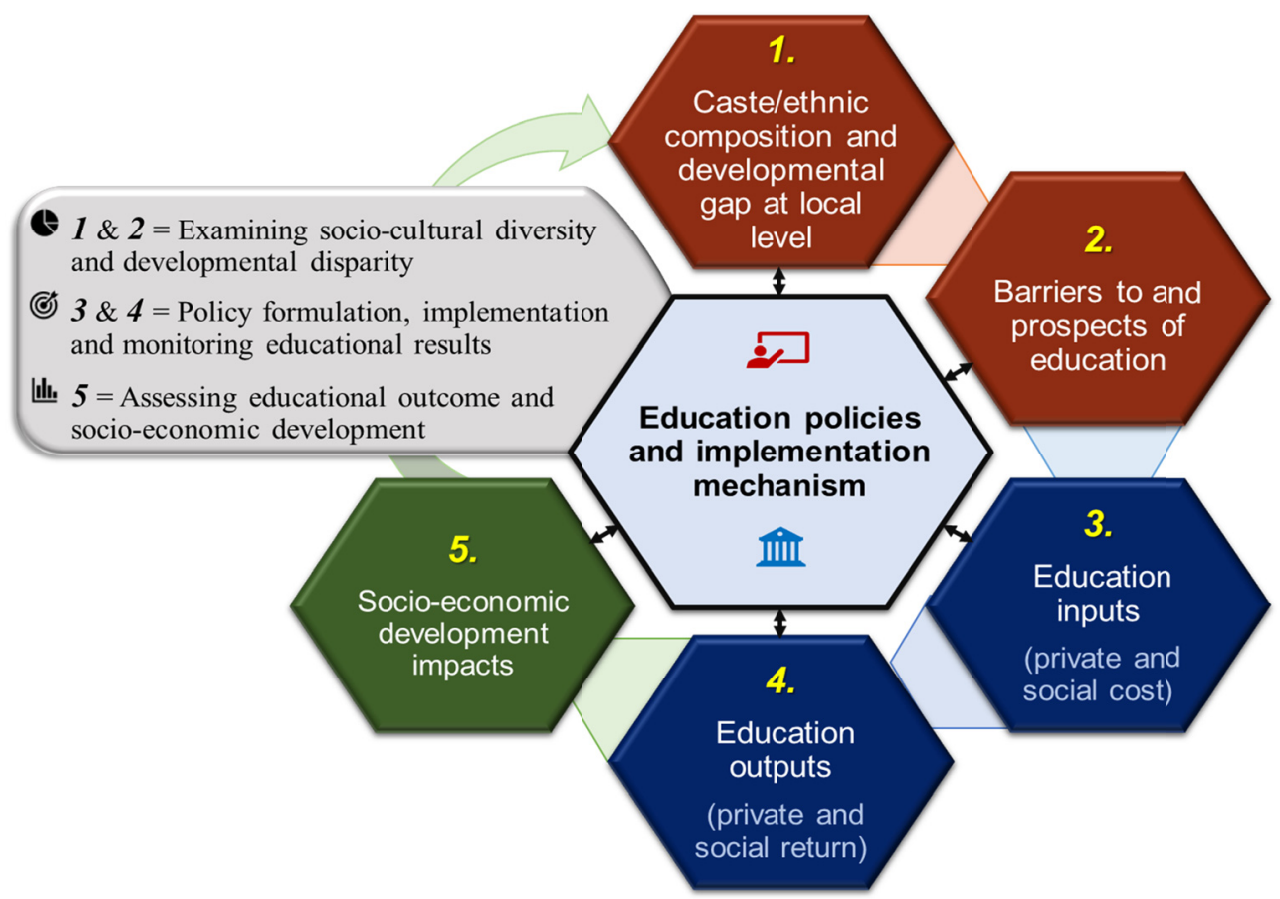

Figure 1. Framework for education development in a diverse society (Source: Author)

The final step involves an assessment of education outcomes and socioeconomic development, analyzing the socioeconomic impacts of education. The existing literature confirms that education bring both monetary and non-monetary benefits and private and social returns, impacting individual and community health, income, and political character. In-depth analysis of these issues can improve policy and implementation mechanisms and the links between education and other factors that are crucial for sustainable socioeconomic development.

Importantly, these steps must be continuous and ongoing, as local situations change over time, as does policy. Education demand and supply also change over time as technologies, and other inputs evolve. To transform society in a peaceful, healthy, and prosperous manner, effective education development must remain dynamic 
and vibrant, addressing barriers to education that are specific to the local context.

\section{Conclusion}

Based on a comprehensive review of the relevant literature and education policy trends in Nepal, this paper advances a framework for education development in a diverse society. After successful elections at all three levels of government, Nepal's new constitution (promulgated in 2015 and implemented in 2017) presents a unique opportunity for education development. Municipal governments now have a mandate to manage school-level education, which was previously under the control of the Ministry of Education's District Education Office. Together with local communities, local government institutions have become the leading stakeholders in transforming education, creating the possibility of rapid positive change.

However, such changes cannot be realized automatically, and local government faces significant challenges in meeting this responsibility effectively. There is a shortage of experts, and local leaders are not sufficiently experienced to handle these challenges appropriately; more generally, local institutions have limited human and financial resources. Nevertheless, this is a historic opportunity to transform an impoverished nation into a prosperous, peaceful, and accepted member of global society. As education is widely seen as the foundation of peace and prosperity, achieving this goal will depend mainly on the performance of autonomous local bodies (Booth, 2013; Barro, 2001).

It is argued that the conceptual framework developed here can contribute to education development in Nepal by assisting policymakers and development practitioners at local level. As local bodies differ in caste/ethnic composition, each municipality needs a unique framework for inclusive education development to inform a) policies that would be effective for all caste/ethnic groups; b) policies that would be effective for specific caste and ethnic groups; and c) policies that would be effective for communities with a specific caste/ethnic composition. This framework can inform the design and implementation of grassroots projects and programs both in Nepal and in other diverse societies in the developing world.

\section{References}

Barro, R. J. (2001). Human capital and growth. American economic review, 91(2), 12-17.

Bastola, K., Neupane, S., Hadkhale, K., \& Kinnunen, T. I. (2016). Unintended Pregnancy among Married Pregnant Women in Nepal. Journal of Womens Health, Issues and Care, 2015. https://doi.org/10.4172/2325-9795.1000197

Bennett, L. (2008). Policy reform and culture change: Contesting gender, caste, and ethnic exclusion in Nepal. Inclusive States, 197.

Bhagavatheeswaran, L., Nair, S., Stone, H., Isac, S., Hiremath, T., Raghavendra, T., ... \& Watts, C. (2016). The barriers and enablers to education among scheduled caste and scheduled tribe adolescent girls in northern Karnataka, South India: A qualitative study. International journal of educational development, 49, 262-270. https://doi.org/10.1016/j.ijedudev.2016.04.004

Bhattachan, K. (2003). Indigenous nationalities and minorities in Nepal. A report submitted to Minority Rights Groups International, London, UK

Bista, M. (2004). Review of research literature on girls' education in Nepal. UNESCO Kathmandu series of monographs and working papers No. 3. Kathmandu: UNESCO.

Booth, A. (2013). Education and economic development in Southeast Asia: myths and realities. In Southeast Asian Paper Tigers (pp. 191-213). Routledge.

Britton, J., \& Vignoles, A. (2017). Education production functions. In Handbook of Contemporary Education Economics, (pp. 246-271). Edward Elgar Publishing. https://doi.org/10.4337/9781785369070.00016

Buttenheim, A. M., \& Nobles, J. (2009). Ethnic diversity, traditional norms, and marriage behavior in Indonesia. Population Studies: A Journal of Demography, 63(3), 277-294. https://doi.org/10.1080/00324720903137224

Central Bureau of Statistics [CBS]. (2011). National population and housing census 2011, National Report. Central Bureau of Statistics (CBS), Kathmandu, Nepal.

Daly, A., Parker, S., Sherpa, S., \& Regmi, U. (2019). Federalization and education in Nepal: Contemporary reflections on working through change. Education 3-13, 1-11 https://doi.org/10.1080/03004279.2019.1599408

Daniel, S. (2006). A review of major obstacles to women's participation in higher education in Kenya. Research 
in post-compulsory education, 11, 85-105. https://doi.org/10.1080/13596740500507995

Department for International Development [DFID]. (2006). Unequal citizens: Gender, caste, and ethnic exclusion in Nepal. Kathmandu: The World Bank.

Dundar, H., \& Haworth, J. (1993). Improving women's access to higher education: A review of World Bank project experience. WPS policy research working paper No. 1106. Washington, DC: The World Bank.

Ekeh, C., \& Smith, M. (2007). Minorities in Burma. Minority Rights Group International, London.

Faguet, J. P. (2013). Decentralization and Governance. World Development, 53, 2-13. https://doi.org/10.1016/j.worlddev.2013.01.002

Glewwe, P., \& Muralidharan, K. (2016). Improving education outcomes in developing countries: Evidence, knowledge gaps, and policy implications. In Handbook of the Economics of Education (Vol. 5, pp. 653-743). Elsevier. https://doi.org/10.1016/b978-0-444-63459-7.00010-5

Gobrin, G., \& Andin, A. (2002). Development conflict: The Philippine experience. Minority Rights Group International and KAMP, London.

Haider, R. (1996). Gender and development. Cairo: The American University in Cairo Press.

Hamamsy, E. (1994). Early marriage and reproduction in two Egyptian villages. Cairo: The Population Council/UNICEF.

Hyde, K. L. A. (1993). Sub-Saharan Africa. In E. M. King, \& A. Hill (Eds.), Women's education in developing countries: Barriers, benefits, and policies (pp. 100-135). Baltimore: The Johns Hopkins University Press.

Jamison, D., \& Lockheed M. E. (1987). Participation in schooling: determinants and learning outcomes in Nepal. Economic Development and Cultural Change, 35(2), 279-306. https://doi.org/10.1086/451586

Kays, L. (2003). Empowering girls in education: Fixing the girls or fixing the problem? Off our backs, 33, 19-24.

Khaniya, T. R. (2007). New horizons in education in Nepal. Kathmandu: Mandala Publications.

Lawoti, M. (2010). Introduction: Ethnicity, exclusion and democracy in Nepal. In M. Lawoti, \& A. Guneratne (Eds.), Ethnicity, inequality and politics in Nepal (pp. 1-17). Kathmandu, Nepal: Himal Books. https://doi.org/10.4324/9781315671307-6

LeVine R. A., LeVine, S. E., \& Schnell, B. (2001). Improve the women: Mass schooling, female literacy, and worldwide social change. Harvard Education Review, 71, 1-52. https://doi.org/10.17763/haer.71.1.154550622x3225u7

Lohani, S., Singh, R. B., \& Lohani, J. (2010). Universal primary education in Nepal: Fulfilling the right to education. Prospects, 40, 355-374. https://doi.org/10.1007/s11125-010-9162-6

Manzoor, A., \& Govinda, R. (2010). Universal primary education in South Asia: A right that remains elusive. Prospects, 40, 321-335. https://doi.org/10.1007/s11125-010-9165-3

Mathema, K. B. (2007). Crisis in education and future challenges for Nepal. European Bulletin of Himalayan Research, 31, 46-66.

Ministry of Education, Science and Technology [MOEST]. (2017). Education in figures 2017 (At a glance report). MOEST, Singhdurbar, Kathmandu.

National Planning Commission [NPC]. (2008). Three year interim plan 2008/09 to 2010/11. Government of Nepal, Kathmandu.

Nepal National Dalit Social Welfare Organization [NNDSWO]. (2015). Human Rights Situation of Dalit Community in Nepal. NNDSWO, Bagdol, Lalitpur.

Neupane, P. (2017). Barriers to Education and School Attainment-Evidence from Secondary Schools in Rural Nepal. International Education Studies, 10(2), 68-83. https://doi.org/10.5539/ies.v10n2p68

Nussbaum, M. (2003). Women's education: A global challenge. Signs: Journal of Women in Culture and Society, 29(2), 325-355. https://doi.org/10.1086/378571

Okediji, O. T. (2005). The dynamics of ethnic fragmentation: a proposal for an expanded measurement index. American Journal of Economics and Sociology, 64(2), 637-662. https://doi.org/10.1111/j.1536-7150.2005.00382.x

Panthi, M. R. (2004). The disability situation in Nepal. A bimonthly web-zone of international disability news 
and views, 24. Retrieved from http://www.disabilityworld.org/06-08_04/gov/nepal.shtml

Phyak, P., \& Ojha, L. P. (2019). Language education policy and inequalities of multilingualism in Nepal. In A. Kirkpatric \& A. J. Liddicoat (Eds.), The Routledge International Handbook of Language Education Policy in Asia (pp. 341-354). Routledge. https://doi.org/10.4324/9781315666235-24

Raynor, J. (2005). Educating girls in Bangladesh: Watering a neighbor's tree? Oxfam, Great Britain (GB). https://doi.org/10.3362/9780855986605.004

Research Centre for Educational Innovation and Development [CERID]. (2005). Access of disadvantaged children in education. Kathmandu.

Research Centre for Educational Innovation and Development [CERID]. (2012). Situation of Water, Sanitation and Hygiene in Nepalese Schools: An Assessment. Kathmandu.

Sapkota J. B., Paudel, D. B., Neupane, P., \& Thapa, R. B. (2019). Preference for sex of children among women in Nepal. Global Social Welfare, 6(2), 69-78. https://doi.org/10.1007/s40609-018-0117-9

Sengupta, J., \& Sarker, D. (2011). Caste and religious diversity on human capital outcome: Evidence from India. Humanomics, 27(93), 166-183. https://doi.org/10.1108/08288661111165213

Shekh, M. N. (2001). Educating women through NGO programs: Contradictions of culture and gender in rural Bangladesh. Retrieved from http:// www.neetred.uio.no/articles/papers_final/Shehk.pdf

Slaughter-Defoe, D. T., Addae, W. A., \& Bell, C. (2002). Toward the future schooling of girls: Global status, issues and prospects. Human Development, 45, 34-53. https://doi.org/10.1159/000048150

Smock, A. C. (1981). Women's education in developing countries: Opportunities and outcomes. New York: Praeger Publishers.

Thapa, A. (2013). Does private school competition improve public school performance? The case of Nepal. International Journal of Educational Development, 33(4), 358-366. https://doi.org/10.1016/j.jijedudev.2012.07.004

Timsina, G. (2004). Samajik nyaya ko seroferoma sikshya (A book on education in the context of social justice in Nepali language). Kathmandu: Students books publishers and distributors.

UNESCO. (2018). The UNESCO Institute for Statistics (UIS) Fact Sheet No. 48. Retrieved from http://uis.unesco.org/sites/default/files/documents/fs48-one-five-children-adolescents-youth-out-school-201 8-en.pdf https://doi.org/10.15220/978-92-9189-133-7-en

United Nations Development Program [UNDP]. (2004). Nepal human development report 2004: Empowerment and poverty reduction. Kathmandu: UNDP, Nepal. https://doi.org/10.18356/68b83600-en

United Nations Educational, Scientific, and Cultural Organization [UNESCO]. (2010). EFA: Global Monitoring Report 2010-Reaching the marginalized. Oxford University Press, U.K.

Unterhalter, E. (2005). Global inequality, capabilities, social justice: The millennium development goal for gender equality in education. International Journal of Educational Development, 25, 111-122. https://doi.org/10.1016/j.ijedudev.2004.11.015

Unterhalter, E. (2008). Global values and gender equality in education: Needs, rights, and capabilities. In S. Fennell, \& M. Arnot (Eds.), Gender education and equality in a global context: Conceptual frameworks and policy perspectives (pp. 19-34). London and New York: Routledge. https://doi.org/10.1080/09540250802211184

Webster, K. L. (1999). Sociocultural barriers to Kenyan girls' education: The case of secondary schools in western provenience (Unpublished $\mathrm{PhD}$ dissertation). Department of Education, The University of Chicago.

World Bank. (1994). Enhancing women's participation in economic development: A World Bank policy paper. Washington, DC.

World Bank. (2006). World development report 2006: Equity and development. Washington, DC.

\section{Copyrights}

Copyright for this article is retained by the author(s), with first publication rights granted to the journal.

This is an open-access article distributed under the terms and conditions of the Creative Commons Attribution license (http://creativecommons.org/licenses/by/4.0/). 